\title{
Stage IV Vaginal Cancer AJCC v8
}

National Cancer Institute

\section{Source}

National Cancer Institute. Stage IV Vaginal Cancer A/CC v8. NCI Thesaurus. Code C139667.

Stage IV includes: IVA: T4, Any N, M0; IVB: Any T, Any N, M1. T4: T umor invading the mucosa of the bladder or rectum and/or extending beyond the true pelvis (bullous edema is not sufficient evidence to classify a tumor as T4). M0: No distant metastasis. M1:

Distant metastasis. (from AJCC 8th Ed.) 